\title{
The Use of Language Aspects as Rhetorical Devices in Obama's Inaugural Addresses
}

Widya Oktarini ${ }^{1 *}$

${ }^{1}$ Universitas Muhammadiyah Jember, Jember, Indonesia

Contact: Widya Oktarini $\bigotimes$ widya.oktarini@unmuhjember.ac.id

\begin{abstract}
This research analyzes language aspects as rhetorical devices in inaugural addresses of the presidents of The United States, Barack $\mathrm{H}$. Obama. Specifically, this research aims at describing the use of diction and language style found in the inaugural addresses. This research is descriptive qualitative using discourse analysis approach. In collecting the data, it uses listening method and note-taking technique. In analyzing the data, it uses contextual method by using sociopragmatics theory. In presenting the result of the analysis, it uses informal method by verbal language. The result of analysis show: the use of language aspects found in inaugural addresses of Obama includes: (a) diction which includes the positive and negative connotation, (b) reference which includes inclusive and exclusive references, (c) language styles includes inclusive and exclusive references, (d) language styles includes repetition (e) the use of figurative language includes metaphor.
\end{abstract}

KEYWORDS:

Language spects;

Rhetorical devices;

Inaugural addresses.

\section{Introduction}

In political discourse, language can have various functions, such as a tool to threaten or to persuade. In the presidential inauguration speech, language functions emphasize more on persuasion and convincing the society. In relation to attempts to persuade listeners (readers), speakers (authors) uses a variety of approaches. One of the most widely used approaches is the use of linguistic aspects which is intended to evoke the emotions of the listener. Those linguistic aspects includes the choice of words, the use of language style and citing opinions of prominent figures. These linguistic aspects are used as the tools of rhetoric. Rhetoric is one of the determinants of speech success. Oka (1990, p. 6) explain that everyone is actually speaking involved with rhetoric. 
Rhetoric is used when someone is preparing, organizing, and displaying his speech. This utilization mostly driven by the desire to get interesting speech or speech that is able to influence others or be able to persuade people other. Knowledge of rhetoric in speech can give character or variety said which is certainly different from other words.

The number of studies related to language aspects and discourse have been conducted by some researchers. Wahyuningsih (2018) explores the use of subjects in Donald Trump's Inauguration Speech. The transcript of the speech is analyzed to describe personal pronouns used by Donald Trump in his inauguration speech. Lexical aspect has proved to be important in research on tense (Shirai, 2011). In addition, Lu et al., (n.d.) have examined scientific writing styles from the perspective of linguistic complexity. Moreover, Nooyen (1999) reports that the languages in these societies have great political significance. In language aspects, Wahyuningsih \& Sofwan (2014) describe the hedges used by the English, Mathematics, Science, Social and Education Management graduate students of State University of Semarang in writing their thesis abstracts

In discussion of rhetoric, language style is known as style. Keraf (2010, p. 113) defines language style or style as a way of expressing thoughts typically through the medium of language both oral and written. Another opinion was also delivered by Dubois (2001, p. 446) in dictionaries de linguistique that Language style is the hallmark of individuals in speeches. Language style is also often used by an orator in a speech. The use of language styles in speech not only to fulfill the element of beauty but also as a medium to convey a certain message. The form of language style can be viewed from various aspects. Based on linguistic elements used, Keraff (2010, p. 116) categorized language styles based on the structure of the sentence and its meaning. The structure of a sentence can be foundation in forming language styles. Classification of language styles can also be determined by whether or not direct meaning is known as figure of speech. The style of language is divided into two, namely rhetorical and figurative language styles. Keraff (2010, p. 129) reveals that the 
style of rhetorical language is solely deviations from ordinary construction to achieve certain effects. Meaning in the style of rhetorical language must be interpreted according to the birth value or the basic meaning. While the figure of figurative language is the style of language formed based on comparison or equation (Keraff, 2010, p. 136). On language style figuratively there are further deviations, especially in the meaning section. Meaning in the style of figurative language cannot be arbitrarily seen from the original meaning.

\section{Method}

Descriptive method is used in this research, which means describing data based on speaker's empirical facts of life. In addition, this study also uses qualitative methods, because the research data is not in the form of numbers but in the form of lingual units such as words, phrases or sentences. Data are collected from speech text by using listening method and note-taking technique. Then the data are analyzed by using contextual methods. Furthermore, the data are presented by informal methods.

\section{Result}

\section{Word Choice (Diction)}

In a communication event, the choice of words needs to be done by keeping in mind the ultimate goal to be achieved through that communication. Word is the channel of ideas to be conveyed to others. Choice of the right words will help to provide understanding and good effect for the reader (listener). To give a certain effect to the listener, speakers usually uses connotative word. Connotative word is a word that contains meaning where the stimulus and response contain emotional values. The connotative meaning occurs because the speaker wants to create feelings of agree, disagree, pleasure, displeasure and so on the listener's side, on the other hand, the selected word shows that the speaker also has the same feelings. Connotation basically arises because of the problem of social relations or interpersonal relationships, which attributes 
our relationship to others (Gorys Keraf, 2009, p. 30). The word connotation is divided into two, namely positive connotations and negative connotations.

\section{The Use of Connotative Word}

\section{Positive Connotation}

Positive connotations are words used for the purpose of generating a positive effect on the listener. In the data in the utterance below, speakers use positive words with the purpose to inflame the spirit of nationalism of American citizens and also to invite and influence all citizens to endlessly fight for the American state.

A word containing positive connotations in the data is described as follows:

(1) ..."At these moments, America has carried on not simply because of the skill or vision of those in high office, but because We the People have remained faithful to the ideals of our forbearers, and true to our founding documents" (01)

(2) "In reaffirming the greatness of our nation, we understand that greatness is never a given. It must be earned. Our journey has never been one of short-cuts or settling for less". (01)

(3) "This is the journey we continue today. We remain the most prosperous, powerful nation on Earth. Our workers are no less productive than when this crisis began. Our minds are no less inventive, our goods and services no less needed than they were last week or last month or last year. Our capacity remains undiminished". (01)

\section{Negative Connotation}

The use of negative connotative words in a speech aims to give negative effects and evoke positive emotions to the audience. In the speech contained in the data, the use of negative connotative words has a function to evoke positive emotion to the audience, especially to remind the audience by making them realize that those negative nature is not good. So, the audience finally realizes and evaluates it and then changes in a better direction and fixes those bad things. In other words, the use of these words has a function to awaken the 
audience and lead to a better thinking. The use of negative connotation words contained in the speech in the data will be described as follows:

(1) "That we are in the midst of crisis is now well understood. Our nation is at war, against a far-reaching network of violence and hatred. Our economy is badly weakened, a consequence of greed and irresponsibility on the part of some, but also our collective failure to make hard choices and prepare the nation for a new age".(01)

(2) "On this day, we come to proclaim an end to the petty grievances and false promises, the recriminations and worn out dogmas, that for far too long have strangled our politics".(01)

(3) "Together, we resolved that a great nation must care for the vulnerable, and protect its people from life's worst hazards and misfortune". (02)

\section{Reference}

Reference is the use of pronouns to refer to a certain reference. Reference is divided into two, they are inclusive reference and exclusive reference.

\section{Inclusive Reference}

Inclusive reference is the reference which include the audience/readers as the part of writer/speaker. Inclusive reference which found in the data can be explained as follows:

(4) "My fellow citizens:

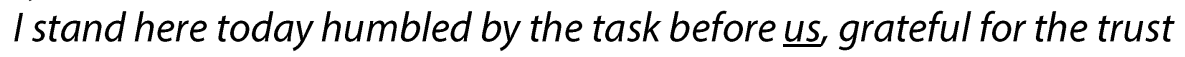
you have bestowed, mindful of the sacrifices borne by our ancestors. I thank President Bush for his service to our nation, as well as the generosity and cooperation he has shown throughout this transition." (01)

(5) We the People

"Forty-four Americans have now taken the presidential oath. The words have been spoken during rising tides of prosperity and the still waters of peace. Yet, every so often the oath is taken amidst gathering clouds and raging storms. At these moments, America has carried on not simply because of the skill or vision of those in high office, but because We the People have remained faithful to the ideals of our forbearers, and true to our founding documents".(01) 


\section{a. Pronoun we, our, us}

(6) "We are the keepers of this legacy. Guided by these principles once more, we can meet those new threats that demand even greater effort - even greater cooperation and understanding between nations. We will begin to responsibly leave Iraq to its people, and forge a hard-earned peace in Afghanistan. With old friends and former foes, we'll work tirelessly to lessen the nuclear threat, and roll back the specter of a warming planet. We will not apologize for our way of life, nor will we waver in its defense, and for those who seek to advance their aims by inducing terror and slaughtering innocents, we say to you now that our spirit is stronger and cannot be broken; you cannot outlast us, and we will defeat you". (01)

\section{b. The Word America}

(7) "We are shaped by every language and culture, drawn from every end of this Earth; and because we have tasted the bitter swill of civil war and segregation, and emerged from that dark chapter stronger and more united, we cannot help but believe that the old hatreds shall someday pass; that the lines of tribe shall soon dissolve; that as the world grows smaller, our common humanity shall reveal itself; and that America must play its role in ushering in a new era of peace".(01)

\section{c. My Fellow American}

(8) "This generation of Americans has been tested by crises that steeled our resolve and proved our resilience. A decade of war is now ending. An economic recovery has begun. America's possibilities are limitless, for we possess all the qualities that this world without boundaries demands: youth and drive; diversity and openness; an endless capacity for risk and a gift for reinvention. My fellow Americans, we are made for this moment, and we will seize it - so long as we seize it together".(02)

\section{d. American People}

(9) "For as much as government can do and must do, it is ultimately the faith and determination of the American people upon which this nation relies. It is the kindness to take in a stranger when the levees break, the selflessness of workers who would rather cut their hours than see a friend lose their job which sees us through our darkest hours. It is the firefighter's courage to storm a stairway filled with smoke, but also a parent's willingness to nurture a child, that finally decides our fate". (01) 


\section{e. This Generation of Americans}

(10) "So it has been. So it must be with this generation of Americans". (01)

\section{f. You and I}

(11) ..."You and I, as citizens, have the power to set this country's course. You and I as citizens, have the obligation to shape the debates of our time -- not only with the votes we cast, but with the voices we lift in defense of our most ancient values and enduring ideals".(02)

\section{g. Each of us}

(12) "Let us, each of us, now embrace with solemn duty and awesome joy what is our lasting birthright. With common effort and common purpose, with passion and dedication, let us answer the call of history and carry into an uncertain future that precious light of freedom". (02)

\section{h. Every American}

(13)"What is required of us now is a new era of responsibility - a recognition, on the part of every American, that we have duties to ourselves, our nation, and the world, duties that we do not grudgingly accept but rather seize gladly, firm in the knowledge that there is nothing so satisfying to the spirit, so defining of our character, than giving our all to a difficult task" (01)

\section{Exclusive Reference}

Exclusive reference is the reference which does not include the reader/listener as the part of writer/speaker.

\section{a. The Word I}

(14) "Today I say to you that the challenges we face are real. They are serious and they are many. They will not be met easily or in a short span of time. But know this, America - they will be met". (01)

(15) "My fellow Americans, the oath I have sworn before you today, like the one recited by others who serve in this Capitol, was an oath to God and country, not party or faction. And we must faithfully execute that pledge during the duration of our service". (02)

\section{b. You}

(16) "Today I say to you that the challenges we face are real. They are serious and they are many. They will not be met easily or in a short span of time. But know this, America - they will be met". (01) 


\section{The Use of Language Style}

\section{Repetition}

Repetition is the repeated phonic, syllabic or word or part of speech that is regarded important to give a stress to an appropriate context. Because it has a high score in oratory, the orator create various kinds of repetition which is principally be based on the place of words which is repeated in line, clause or sentence (Keraf, 1993, p. 127). Those kinds of repetition which are found in the data such as:anaphor, epizeuksis, tautotes, epistrofa, mesodiplosis and anadiplosis.

\section{a. Anaphor}

Anaphor is the repetition in the form of the repeated first word in each line or the next sentence. Kinds of anaphor which are found in the data is described as follows:

(17a)"for us, they packed up their few worldly possession and travelled across ocean in search of a new life".(01)

(17b) "for us, they toiled in sweatshops and settled the West; endured the last of the whip and plowed the hard earth".(01)

(17c)"For us, they fought and died, in places like Concord and Gettysburg; Normandy and KheSahn". (01)

(18) ....We will build the roads and bridges, the electric grids and digital lines that feed our commerce and bind us together. We will restore science to its rightful place, and wield technology's wonders to raise health care's quality and lower its cost. We will harness the sun and the winds and the soil to fuel our cars and run our factories. And we will transform our schools and colleges and universities to meet the demands of a new age. All this we can do. And all this we will do".(01)

(19a)"Together, we determined that a modern economy requires railroads and highways to speed travel and commerce, schools and colleges to train our workers". (02) 
(19b) "Together, we discovered that a free market only thrives when there are rules to ensure competition and fair play". (02)

(19c)"Together, we resolved that a great nation must care for the vulnerable, and protect its people from life's worst hazards and misfortune". (02)

\section{b. Epizeuksis}

Epizeuksis is a direct repetition, meaning of the important word is repeated several times in a row. Repetition of types of episodes contained in the data will be explained in the following speech:

(20)"My fellow Americans, the oath I have sworn before you today, like the one recited by others who serve in this Capitol, was an oath to God and country, not party or faction. And we must faithfully execute that pledge during the duration of our service. But the words I spoke today are not so different from the oath that is taken each time a soldier signs up for duty or an immigrant realizes her dream. My oath is not so different from the pledge we all make to the flag that waves above and that fills our hearts with pride". (02)

\section{c. Epistroph}

Epistroph is a repetition in the form of repeated word or phrase in the end of the line or sequential sentences. Epistroph in the data can be seen from this following utterance:

(21) "Our challenges may be new. The instruments with which we meet them may be new".(01)

\section{Metaphor}

Metaphor is kinds of analog which compare two things directly, but in a short form (Gorys Keraf, 2009, p. 139). Metaphor is usually used with the purpose to make the words more beautiful and can attract listener, so the message conveyed can be accepted by listener. Metaphors that are found in the data are:

(22) "Yet, every so often the oath is taken amidst gathering clouds and raging storms". (01) 
(23)"In the face of our common dangers, in this winter of our hardship, let us remember these timeless words. With hope and virtue, let us brave once more the icy currents, and endure what storms may come". (01)

\section{Discussion}

\section{Positive Connotation}

In this utterance (1), Obama uses a word that has positive connotations, that is faithful. The word faithful has an emotive charge that can trigger the spirit of American citizens to continue to carry out their duty building the United States. With the word "faithful", citizens will feel that the attitude of faithful is the character of the American nation. So, those who regards themselves as Americans will feel ashamed of not having that trait. Based on this, the selection of the word "faithful" is intended to arouse the spirit of American citizens to continue performing their duties as citizens.

In this utterance (2), Obama uses the word greatness to influence the audience to work hard. With the word greatness in this speech, Obama intends to rekindle the spirit and invite all citizens to achieve the greatness of the United States. This word is also used to refer to the success that America can achieve. By using this word, Obama hopes people can see the amount of capacity that can be achieved by the United States if all citizens are willing to work together to achieve it. Based on this, the selection of the word greatness in this speech has a function to influence the spirit of American citizens to work in achieving success because this word has an emotive value to change the minds of the audience to agree with Obama's opinion.

In this utterance (3), Obama uses the word prosperous, powerful, no less productive, no less inventive, and undiminished. These words, have an emotive value that can affect the audience mentally. With the use of these words, Obama hopes that all Americans know that the United States is a very potential country to remain a superpower, so they keep trying to continue the journey that has brought them to this point. With the use of these words as well, it is hoped that the citizens will inflame their nationalistic souls to tirelessly fight for 
America's sake. For this reason, the selection of these words in this utterance has the function to generate a positive effect for the citizen by staying effortless and never tired to continue the journey of America that has been a superpower country.

\section{Negative Connotation}

In this utterance (1), Obama uses words that have negative connotations represented by the words crisis, war, violence and hatred, badly weakened, collective failure, and hard. These words have emotive values that can affect the mentality of the audience. In this context, the expected effect with the use of these negative words is the positive emotion in the audience. By using these negative words, Obama hopes the American people are aware of the circumstances and difficulties faced by the United States today. At this time, the United States is in crisis, engaging in war, fighting a network of far-reaching violence and hatred, a weak economy, and collective failure by Americans in making difficult choices. By presenting these facts, Obama intends to raise the awareness of all Americans that today America needs the spirit and action for a better future. With the selection of those negative words also, Obama intends to remind citizens to evaluate these bad things, and find a right way out for the right problem. Based on this description, the negative word connotation of this speech has a function to raise citizens' awareness of the current state of America, to then evaluate the cause, and to find the most appropriate solution for the future.

At this data (2), Obama uses words that have negative connotations which is represented by the words petty grievances, false promises, the recriminations and worn out dogmas. These words contains negative emotion that can affect audience's emotion. By using these words, Obama intends to make the audience realize about those negative things and emphasize that those suffering in their life has to be stopped. Therefore, Obama hopes that all of the citizen is affected by these statement and struggle to stop the suffering by 
deciding to gather in Obama's speech in their own awareness. The use of those words indirectly stated that the previous governments have not given the meaningful change to American society, because they just gave false promises and worn out dogmas to the society without real change to the society life.

At this utterance (3) Obama uses the words that have negative connotations which is represented by the words vulnerable, worst hazard and misfortune. The use of these words is intended to give a negative effect to the audience. In this case, Obama intends to affirm the society that word hazards and misfortune must be avoided to happen to them because they are vulnerable to those things. In this statement, Obama intended to invite the society altogether to avoid those bad things by working together to America.

\section{Inclusive Reference}

At this utterance (4), the use of my fellow citizens is the reference used by Obama to intimate himself with audience and show solidarity to all American citizen. The use of the word my fellow citizens is Obama's effort to humble and equalize himself with the society so the solidarity as the American citizen can be felt without any defenses in status between ordinary society and the president. By this emotional closeness, Obama hopes what he conveyed can be accept easily by all American. Equality impression which is shown by Obama make the society feel equal in status that is the equality as American society.

At this utterance (5), Obama use the reference we the people as the effort to build emotional closeness with all American citizen. Beside, the word we the people is a sacred in reference because it is based on the constitution which be the ideology of American's life. By the reference, We the people Obama regards that himself is as equal as the American citizen who has the same right and obligation. By this emotional closeness and equality, Obama indirectly try to affect and energize nationalism spirit to American citizen to stay faithful to the noble ideas and documents which have been formulated by the founding father of America. Therefore, the reference "We the people" in this utterance 
has the function to build emotional relationship with audience and also make the equality by plotting the society as the doer of activity and noble ideas and remind the society with the constitution which is the foundation to American's life.

\section{a. Pronoun we, our, us}

At this utterance (6), Obama uses the reference with pronoun we, our and us as the effort to build emotional intimacy with all citizens. by referring we, our, and us, citizen as the audience feel intimate and equal with Obama. By the reference in this utterance, Obama intends to make all American citizen get involve by giving a role to keep the American country noble ideas and keep the peace of America and all of the world.

\section{b. The Word America}

At this utterance (7), Obama uses the word America to call all the American citizen, including himself. The intention of using this word is that all American citizen feel as one unity, as one soul and nation that have the same obligation to defend the country. He also intended to ask all American citizen as another part of the doer to create peace in the new era. Therefore, the used of the word America in this utterance has a function to place the citizen as the doer in building the country together with himself.

\section{c. My Fellow American}

At this utterance (8), Obama uses the word my fellow Americans which is used to make a close relationship with American citizen. By this emotional bonding, it is hoped that what Obama said can be accepted sincerely by the society. Therefore, the invitation o build the nations together with himself under his authority can be accepted sincerely by the society. So, the goal to be achieved by using this word is to persuade society to make use of the potency of each individu to create a new discovery which can lift the nation self-esteem. 


\section{d. American People}

In this utterance (9), Obama uses the word America to make all the citizen take a part as the doer who will build the nation together with himself under his authority. The purpose of using this word is to build emotional bonding with the society. Beside, this word is also aimed to persuade and convince citizen to help government build the nation with the sincerity to help people suffering from disaster, help people to keep in their job, and the generosity of parents to grow their children up.

\section{e. This Generation of Americans}

In this utterance (10) Obama uses the word this generation of Americans to include all citizen as the part of American Nation which have the same responsibility to always be faithful to American noble ideals. This reference is intended to refer all American citizen. Therefore, in this context, Obama stated that he, himself who is responsible for that noble ideas, and include all citizen in it, because American generation is the citizen now.

\section{f. You and I}

In this utterance (16), Obama refer the society with the word you and I. This reference refer to Obama, himself and also all citizen. Therefore, this reference represent all American citizen. Obama also intend to include all citizen to set the purpose of American nation and also to defend American noble ideals that has already been existed. In conclusion, it can be stated that this reference has a function to make Obama equal with all American citizen and also participate them to build the nation together, in this contet is under Obama's government.

\section{g. Each of us}

In this utterance, Obama uses reference each of us that refer to Obama and also all American citizen. By using this reference, Obama intended to invite citizen as the part of American nation to embrace each other to manifest common goals and dedication wholeheartedly. Therefore, this reference has a function 
to persuade all American citizen with Obama to work together for common goals.

\section{h. Every American}

In this utterance (13), Obama uses the reference Every American that refer to all American citizen, including he, himself. The intention of this reference is to affect and invite all citizen to be back to the noble ideas and also do self, nation and world's obligation wholeheartedly which is the American character. Based on this, this reference has a function to inflame the spirit of nationalism to finish the difficult country's development.

\section{Exclusive Reference}

\section{a. The Word I}

In this utterance (14), Obama used the reference / that refer to Obama, himself. This reference, does not involve American citizen because Obama just place himself as the doer in the context of the speech. The context of this speech is Obama that remind citizen about condition that will be faced by American nation in the future based the existed facts. By this reference, Obama wants to use his authorization as the president by giving a command indirectly to prepare themselves which will be faced by American nation. Therefore, the reference I in Obama's utterance has a function to use the authorization of power to himself.

In this utterance (15), Obama used the reference $/$ that refer himself. The use of the word $I$ to state himself as the source of information. In this case, Obama confirmed the information that the promise he said in the innaugural address and witnessed by all citizen is the sacred promise. Therefore, that promise must be fulfilled and done well. In conclusion, the use of the exclusive reference $/$ by Obama is intended to place himself as the information and promise provider to the American society. 


\section{b. You}

In this utterance (16), Obama used the reference you for not involving American citizen as the part of himself. In this context, Obama stated that the challenge that will be faced by American citizen is serious and many, therefore it need to do actions to face those challenges and involve all American citizen. So, the reference in this utterance is to refer to all American society.

\section{The Use of Language Style}

\section{Repetition}

\section{a. Anaphor}

In the data (17) the repetition used is functioned to confirm the condition which is experienced by the man and woman labour which don't know by society which had merit to bring American nation to go out of difficult times. In the utterance (17), repetition occur at the utterance (17) b and (17) c which is repeated the (17) a data for the word for us. So, the function of this repetition in this utterance is to confirm and persuade American citizen indirectly to work hard in order to continue the big achievement by those pioneer (ancestor) of this nation.

Repetition in this utterance (18) is in the first word in every sentence. In this utterance, Obama used the issue of the plan which will be done to build the American nation better. The context of this utterance is the information told by Obama about many things that have to be done to build American nation, so it need a brave and direct action from the citizen. Therefore, the function of this utterance is to persuade all citizens to do action to change the nation by deciphering things that will be done. This repetition also functions to decipher and confirm things that will be done as a promise of the performance of Obama's government that will be started.

In this data (19), utterances are found utilizing repetitions in the form of solicitation through the word "together" on data (19) a which is indicated by repetition of the same words in data (19) b and (19) c. The context in this 
utterance is that Obama invites/ persuade all Americans to renew and move forward together in an effort to build a better American country. Therefore, the repetition of the word "together" in the speech has a function to confirm and convince and encourage all Americans in order to be willing to move forward together and improve themselves for the better of the country.

\section{b. Epizeuksis}

In the utterance (20) repetitions found on the word oath (promise). The context of this speech is that Obama reiterated the promise he had made that Obama promised to God and the state, not to the party that had brought him to become president. Therefore, the promise must be fulfilled and implemented during his leadership period. Obama also stressed that the promises he made were as sacred as the promise of soldiers entering the military who were willing to sacrifice for the sake of the nation and state above personal interests. So, it can be concluded that the repetition of the word oath in this speech has a function to emphasize how important the meaning and implementation of the promises made by Obama during this inauguration.

\section{c. Epistroph}

The utterance on data (21) uses repetitions on the word may be new at the end of the sentence. The context of this speech is Obama's expression of the new challenges that will be faced by the United States. Obama uses repetitions in this speech to emphasize that the challenges facing the American country will be difficult, as well as the tools used to deal with them. So, the function of repetition here is to emphasize the idea of the topic that Obama is talking about, in this case is about the challenges facing the American state that are not easy. Therefore, the values that exist in ourselves are needed, namely working to develop America happily, not by force.

\section{Metaphor}

In this utterance (22), Obama uses a metaphor that compares the situation that is serious and raging with clouds and storms. Obama uses a comparison of 
situations with nature. This metaphor is a direct comparison, which directly compares emergency situations with gathering clouds and raging storms. This metaphor means that gathering clouds means rain will occur. This is connoted with a situation that is not good or emergency. Likewise the case with a raging storm. The storm is connoted with a chaotic and bad situation. This is interpreted from the true meaning of disaster. Therefore, it can be concluded that this metaphor describes the state of the United States at that time which was experiencing difficult conditions and problems that had to be faced. The relationship with the context in this speech is taking an oath as president when the country experiences a difficult situation like this. Based on this description, it can be concluded that this metaphor has a function to influence the mind of the listener that the task currently being carried out by Obama as president is not easy considering the current state of the United States. Therefore, Obama in his subsequent speech emphasized that in the midst of such conditions, the American president continued to carry out his duties, not because of responsibility for high office, but because of the character of Americans who were loyal to ancestral ideals and also the formulated laws by the state. This statement indirectly reveals that Obama is the one who embraces this principle. Thus, the use of the metaphor in this speech can also be intended to provide a positive image of Obama in the mind of the audience.

In this utterance (23), Obama uses the natural metaphor shown by the words winter, icy currents, and storms. The use of these words is intended to compare the state of the United States with the state of nature. The comparison used here compares the difficulties with winter (winter) where the season is a difficult season because there is snow that inhibits the activities of residents outside the home, in addition, the cold air also makes people unable to consume certain foods or drinks. Therefore, the word difficulty is compared to the word winter because it is considered to have similarities. In addition, the use of the words icy currents and storm is also used to describe the difficulties and challenges that will be faced by Americans. With the use of these words, 
Obama intends to give citizens an idea of the difficulties and obstacles that the American country will face in the future, by comparing them with difficult natural conditions. Thus, it is expected that the people can understand the intent and purpose of the sentence more easily. In addition, the use of metaphor is also intended to strengthen the determination of all citizens to stay in the midst of difficult state conditions as described by the natural conditions. Finally, it can be concluded that the use of metaphor here is intended to influence the minds of the audience to continue to strengthen the determination of all citizens by providing a comparison with the state of nature.

\section{Conclusion}

To summarize, the study of language aspects as rethorical devices is considerably interesting. In this sense, this study explores the language aspects as rhetorical devices in inaugural addresses of the presidents of The United States, Barack H. Obama. The result of analysis reveals that the use of language aspects found in inaugural addresses of Obama includes: (a) diction which includes the positive and negative connotation, (b) reference which includes inclusive and exclusive references, (c) language styles includes inclusive and exclusive references, (d) language styles includes repetition (e) the use of figurative language includes metaphor.

\section{References}

Dubois, J. (2001). Dictionnaire de linguistique. Retrieved from https://books.google.co.id/books?id=2iSTQgAACAAJ

Gorys Keraf, D. (2009). Diksi dan Gaya Bahasa. Retrieved from https://books.google.co.id/books?id=2zm9pAbUHP8C

Keraf, G. (1993). Komposisi: sebuah pengantar kemahiran bahasa. Retrieved from https://books.google.co.id/books?id=r4ZkAAAAMAAJ

Keraff, G. (2010). Argumentasi dan Narasi. Jakarta: PT Gramedia Pustaka Utama.

Lu, C., Bu, Y., Wang, J., Ding, Y., Torvik, V., \& Schnaars, M. (n.d.). Examining Scientific Writing Styles from the Perspective of Linguistic Complexity Examining Scientific Writing Styles from the Perspective of Linguistic Complexity. 1-35.

Nooyen, J. (1999). Issues in Applied Linguistics. Issues in Applied Linguistics, $10(1)$. 
Oka, I. G. N. (1990). Retorik: kiat bertutur. Retrieved from https://books.google.co.id/books?id=G303twAACAAJ

Shirai, Y. (2011). Lexical and Grammatical Aspect in Language Acquisition, Processing, and Disorders. 41-57.

Wahyuningsih, S. (2018). Personal Pronouns in Donald Trump 's Inauguration Speech. 2nd English Language and Literature International Conference (Ellic) Proceedings, 2, 346-350.

Wahyuningsih, S., \& Sofwan, A. (2014). Hedges in Thesis Abstracts of Graduate Students of Semarang State University. English Education Journal, 4(2), 75-81. 